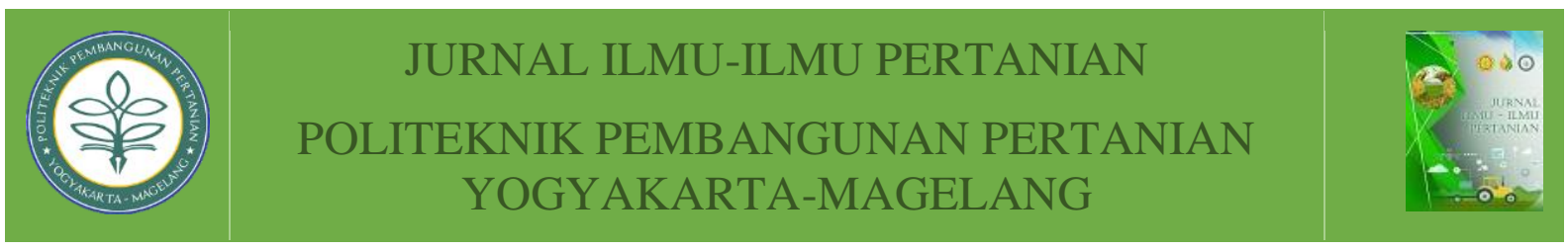

\title{
PENGARUH FITO-PESTISIDA TERHADAP HAMA PENGGEREK DAUN SERPENTIN (Liriomyza sp.) PADA BUDIDAYA TANAMAN KRISANTHEMUM (Chrysanthemum morifolium Ramat)
}

\author{
Endah Sri Pujiati ${ }^{1}$, Anang Sucahyo ${ }^{2}$ \\ ${ }^{1}$ Dinas Pertanian dan Pangan Kabupaten Kulon Progo, Kulon Progo, 55652 \\ ${ }^{2}$ Dinas Pertanian dan Pangan Kabupaten Kulon Progo, Kulon Progo, 55652
}

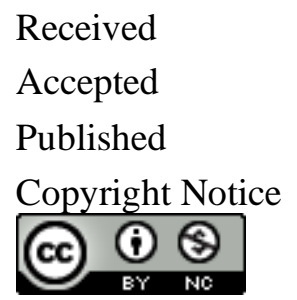

$$
\begin{array}{ll}
: & \text { February } 15^{\text {th }}, 2021 \\
: & \text { April } 10^{\text {th }}, 2021 \\
: & \text { June } 17^{\text {th }}, 2021
\end{array}
$$

: Authors retain copyright and grant the journal right of first publication with This work is licensed under a Creative Commons Attribution-Non Commercial 4.0 International License.

\begin{abstract}
ABSTRAK: Hama Penggerek Daun Serpentin (Liriomyza sp.) merupakan salah satu hama kritis yang merugikan kualitas Krisan. Untuk pengendalian hama, biasanya digunakan pestisida kimia sintetis oleh petani. Tujuan penelitian ini adalah untuk mengukur pengaruh pengendalian phyto-pestisida terhadap penggerek daun serpentin (Liriomyza sp) dalam budidaya hasil tanaman Krisan (Chrysanthemum morifolium Ramat). Rancangan Acak Kelompok Lengkap (RAK) diterapkan dengan menggunakan 2 faktor (pestisida dan frekuensi) dan 3 ulangan. Hasil penelitian menunjukkan pengaruh interaksi antara jenis pestisida dan frekuensi pemberian semua parameter yang diamati. Relative Control Effectivity (RCE) phytopestisida (90,47\%) dengan pestisida kimia (85\%) berpengaruh sama dalam mengendalikan serangan Liriomyza sp. pada pertumbuhan krisan. Pemberian phyto-pestisida mampu menurunkan intensitas serangan penggerek daun serpentin (Liriomyza sp) dan mempunyai keefektifan yang sama dengan pestisida kimia.
\end{abstract}

Kata Kunci : Krisan Morifolium, Pestisida Nabati, Liriomyza sp., Efektivitas Pengendalian Relatif.

ABSTRACT: The Serpentin Leaf Borer (Liriomyza sp.) Is one of the critical pests which adversely affect the quality of Chrysanthemum. For pest control, usually synthetic chemical pesticides are used by farmers. The purpose of this study was to measure the effect of phytopesticide control on serpentine leaf borer (Liriomyza sp) in the cultivation of Chrysanthemum (Chrysanthemum morifolium Ramat) crops. Complete Randomized Block Design (RBD) was applied using 2 factors (pesticides and frequency) and 3 replications. The results showed the effect of the interaction between the types of pesticides and the frequency of application of all observed parameters. Relative Control Effectivity (RCE) phyto-pesticides (90.47\%) with chemical pesticides (85\%) have the same effect in controlling attacks by Liriomyza sp. on chrysanthemum growth. The application of phyto-pesticides can reduce the intensity of the 
serpentine leaf borer (Liriomyza sp) and has the same effectiveness as chemical pesticides.

Keywords : Morifolium Chrysanthemum, Vegetable Pesticides, Liriomyza sp., Relative Control Effectiveness.

\section{PENDAHULUAN}

Tanaman krisan di Daerah Istimewa Yogyakarta (DIY) pertama kali dikembangkan oleh sebuah perusahaan swasta di daerah Kecamatan Cangkringan, kabupaten Sleman. Perusahaan ini aktif hampir bersamaan dengan terjadinya krisis moneter tahun 1998 di Indonesia, namun karena tidak dapat menembus pasar di Yogyakarta kegiatan budidaya tidak dilanjutkan. Baru tahun 2005 para peneliti Balai Pengkajian Teknologi Pertanian (BPTP) Yogyakarta bekerja sama dengan petani kecil di Dusun Wonokerso, Kelurahan Hargobinangun, Kecamatan Pakem, Kabupaten Sleman, Daerah Istimewa Yogyakarta mulai dikembangkan. Pada tahun 2009 budidaya bunga krisan dikembangkan di wilayah Kecamatan Samigaluh, Kabupaten Kulon Progo (Anonim, 2008).

Upaya untuk meningkatkan produksi bunga potong krisan baik kualitas maupun kuantitasnya, banyak menemui kendala. Kendala - kendala yang dihadapi adalah kebutuhan benih bermutu masih mengandalkan benih dari luar, adanya serangan Organisme Pengganggu Tumbuhan (OPT), dan kelembagaan yang belum profesional. OPT pada tanaman krisan dapat terbawa oleh tanaman atau bagian dari tanaman, benih, atau faktor lain seperti tanaman inang di sekitar pertanaman, angin, air tanah, dan media tanam. Benih merupakan faktor pembawa dan penyebar OPT yang paling berpotensi, baik hama maupun patogen, terutama penyakit-penyakit yang bersifat laten yang dapat disebabkan oleh bakteri, cendawan, maupun virus (Anonim, 2011).

Kendala utama usaha tani tanaman krisan di Kecamatan Samigaluh, Kabupaten Kulon Progo, D. I. Yogyakarta adalah adanya gangguan lalat pengorok daun (Liriomyza sp.). Serangga dewasa menusuk daun-daun muda dengan ovipositornya, alat ini selain untuk makan (mengisap cairan) juga untuk meletakkan telur. Telur akan menetas menjadi larva dalam beberapa hari, kemudian larva tersebut membuat lubang korokan sehingga pada daun terjadi aluralur bekas kerokan yang berliku bekas kerokannya yang berwarna putih. Pada intensitas serangan tinggi bagian daun dan kadang-kadang seluruh tanaman terlihat putih dan populasi pupa dapat mencapai 40 pupa. Kerusakan yang diakibatkan Liriomyza sativae terjadi pada jaringan palisade daun saat larva membuat liang korokan yang memiliki ciri khas berbentuk linear, mengular (serpentine), dan kotorannya lebih lebar daripada korokan species lainnya (Herlinda, 2003).

Pengendalian OPT pada tanaman krisan seharusnya tetap menerapkan sistem Pengendalian Hama Terpadu (PHT), dengan menerapkan prinsip-prinsip PHT. Sistem Pengendalian Hama Terpadu (PHT) harus mengacu pada penekanan pengendalian tetap pada cara-cara bercocok tanam dan pendayagunaan musuh alami hama, dengan insektisida kimia hanya digunakan bila cara-cara non kimiawi tidak bisa menekan populasi hama pada tingkat ambang batas ekonomi (atau yang merugikan) (Winarno, 2013). Adapun tujuan penelitian ini adalah mengetahui pengaruh konsentrasi dan frekuensi pemberian pestisida nabati terhadap efektivitas pengendalian lalat Liriomyza sp., pertumbuhan, dan hasil tanaman krisan, mengetahui interaksi pengaruh konsentrasi dan frekuensi pemberian pestisida nabati terhadap efektivitas pengendalian lalat Liriomyza sp., pertumbuhan, dan hasil tanaman krisan. 
Diduga pemberian pestisida nabati dengan konsentrasi $1 \%$ dan frekuensi pemberian seminggu 2 kali efektif dapat mengendalikan hama pengorok daun (Liriomyza sp.) pada tanaman krisan, sehingga memberikan pertumbuhan dan hasil krisan terbaik.

\section{METODE PENELITIAN}

Penelitian dilaksanakan di kubung (rumah plastik) lahan milik petani di Dusun Jetis, Desa Gerbosari, Kecamatan Samigaluh, Kabupaten Kulon Progo, D. I. Yogyakarta. Ketinggian tempat $\pm 520 \mathrm{~m}$ di atas permukaan laut (dpl), jenis tanah latosol cokelat, suhu antara $20-30^{\circ} \mathrm{C}$, kelembaban antara $80-90 \%, \mathrm{pH}$ tanah 5 6. Penelitian dilaksanakan mulai bulan Juni sampai dengan September 2019.

Penelitian ini dilaksanakan dengan percobaan lapangan disusun dalam Rancangan Acak Kelompok Lengkap (RAKL) 2 faktor dan 3 ulangan. Faktor pertama adalah konsentrasi pestisida $(\mathrm{P})$ terdiri dari 3 taraf yaitu : Pestisida nabati konsentrasi $0,5 \%$ (P1), Pestisida nabati konsentrasi $1 \%(\mathrm{P} 2)$, dan Pestisida kimia konsentrasi $0,1 \%$ (P3). Faktor kedua adalah frekuensi pemberian pestisida $(\mathrm{F})$ terdiri dari 2 taraf yaitu: Frekuensi pemberian pestisida seminggu 2 kali (F1), dan Frekuensi pemberian pestisida seminggu 1 kali (F2).

\section{Pelaksanaan Penelitian:}

1. Persiapan lahan, penanaman, pengaturan dan penambahan cahaya, pemupukan, pemeliharaan tanaman meliputi (penyulaman, penyiangan, pengairan, perompesan daun), pembuangan titik tumbuh bunga samping, dan panen.

2. Pengendalian Hama Lalat Liriomyza sp.

Pengendalian lalat Liriomyza sp. Pada tanaman krisan menggunakan pestisida nabati yang terdiri dari: urin kelinci, daun mimba, serai wangi, bawang putih, lengkuas, umbi gadung, EM4, dan tetes tebu. Cara pembuatannya yaitu perajang gadung sebanyak $5 \mathrm{~kg}$ dan dikeringanginkan, daun mimba $0,25 \mathrm{~kg}$, serai wangi $0,5 \mathrm{~kg}$, bawang putih $0,5 \mathrm{~kg}$, lengkuas $0,5 \mathrm{~kg}$ dicacah dan ditumbuk sampai halus, kemudian dimasukan ke dalam ember yang berisi urin kelinci 5 liter, ditambah EM4 $25 \mathrm{ml}$, dan tetes tebu $50 \mathrm{ml}$. Larutan diperam selama 3 minggu, kemudian larutan disaring menggunakan kain kasa. Pestisida nabati disemprotkan pada seluruh daun tanaman krisan. Konsentrasi 5 cc/liter air, dosis 750 - 1000 cc larutan/petak/minggu dan 2 kali seminggu. Konsentrasi $10 \mathrm{cc} / \mathrm{liter}$ air, dosis 750 - $1000 \mathrm{cc}$ larutan/petak/minggu dan 2 kali seminggu. Pengendalian menggunakan pestisida kimia berbahan aktif Abamektin dengan konsentrasi $1 \mathrm{cc} /$ liter air, dosis 750 - 1000 cc larutan/petak/minggu serta 2 kali seminggu. Penyemprotan dilakukan mulai 2 sampai 12 minggu setelah tanam pada pagi hari.

3. Pemasangan Perangkap Kuning

4. Variabel yang diamati

Variabel yang diamati dalam penelitian ini adalah :

a. Pertumbuhan Tanaman

1) Tinggi tanaman

2) Jumlah daun

b. Hasil Tanaman

Pengukuran dilakukan sesuai dengan syarat mutu bunga krisan potong segar yang layak jual dan memenuhi grade AA, A, B, C respon yang diamati meliputi :

1) Panjang tangkai tanaman

2) Diameter bunga

3) Diameter tangkai bunga

4) Pada bunga dan daun (bekas serangan hama dan penyakit)/kotoran maks.

5) Keadaan tangkai bunga.

c. Organisme Pengganggu Tumbuhan (OPT)

1) Intensitas serangan Liriomyza sp. dianalisis dengan rumus 
Intensitas Serangan $=\frac{\sum(n \times v)}{Z \times N} \times 100 \%$

Keterangan :

IS : Tingkat kerusakan tanaman (\%)

$\mathrm{n}$ : Jumlah daun yang terserang pada skala tertentu

$\mathrm{v} \quad$ : Nilai kerusakan tanaman (seluruh daun)
$\mathrm{N}$ : Jumlah daun yang diamati

$\mathrm{Z}$ : Nilai skala kerusakan tertinggi $(\mathrm{v}=5)$

Penentuan tingkat kerusakan dilakukan dengan menilai kerusakan tanaman menggunakan skala $1-5$ berdasarkan kriteria berikut (Martini et al., 2005).

Tabel 1. Kategori Serangan Liriomyza sp.

\begin{tabular}{cl}
\hline Nilai & \multicolumn{1}{c}{ Kategori Serangan } \\
\hline 1 & Tidak ada kerusakan \\
2 & Kerusakan kecil, umumnya terbatas pada bagian bawah tanaman, sekitar $1-25 \%$ kerusakan \\
3 & $\begin{array}{l}\text { Kerusakan sedang, umumnya terbatas pada bagian bawah dan tengah tanaman, sekitar }>25-50 \% \\
\text { kerusakan }\end{array}$ \\
& Kerusakan pada seluruh bagian bawah tanaman kecuali daun-daun pucuk, $>50-75 \%$ kerusakan \\
5 & Sebagian besar dari keseluruhan bagian tanaman rusak, $>75-100 \%$ kerusakan \\
\hline
\end{tabular}

Sumber : Martini et al. (2005)

2) Keefektifan Relatif Pengendalian (KRP) dihitung dengan rumus

$\mathrm{KRP}=\frac{I S T P-I S P}{I S T P} \times 100 \%$

Keterangan :

KRP = Keefektifan Relatif Pengendalian

IS TP = Intensitas serangan pada petakan tanpa perlakuan

(Khusus perhitungan KRP di setiap blok terdapat petak perlakuan tanpa

pestisida nabati dan pestisida kimia)

IS P = Intensitas serangan pada petakan perlakuan

Tabel 2. Kriteria Keefektifan Relatif Pengendalian

\begin{tabular}{cc}
\hline Nilai KRP & Kategori Keefektifan \\
\hline KRP $\geq 80 \%$ & Sangat efektif \\
$60 \% \leq \mathrm{KRP}<80 \%$ & Efektif \\
$40 \% \leq \mathrm{KRP}<60 \%$ & Agak efektif \\
$20 \% \leq \mathrm{KRP}<40 \%$ & Kurang efektif \\
$\mathrm{KRP}<20 \%$ & Tidak efektif \\
\hline
\end{tabular}

Sumber : Martini et al. (2005)

\section{Pengolahan Data}

Dari variabel yang diamati dilakukan uji Anova dilanjutkan dengan uji Duncan. Kombinasi meliputi tanpa perlakuan, biopestisida $5 \% 1 \mathrm{x}$, biopestisida $10 \% 1 \mathrm{x}$, kimia $1 \mathrm{x}$, biopestisida $5 \% 2 \mathrm{x}$, biopestisida $10 \% 2 \mathrm{x}$ dan kimia $2 \mathrm{x}$. Analisis meliputi tinggi tanaman per minggu, jumlah daun per minggu, panjang tangkai tanaman $(\mathrm{cm})$, jumlah daun $2 / 3$ bag tangkai bunga, diameter bunga $(\mathrm{mm})$, diameter tangkai bunga ( $\mathrm{mm}$ ), benda asing (sisa hama / penyakit) (\%) dan keadaan tangkai dan intensitas serangan. Selanjutnya semua perlakuan juga diuji untuk keefektifan relatif pengendalian. Uji pengaruh biopestisida dilihat dari perbedaan variabel yang diamati antara perlakuan biopestisida dan kimia serta kontrol (tanpa perlakuan) dengan tingkat signifikansi $5 \%$.

\section{HASIL DAN PEMBAHASAN}

Dari Tabel 3 dan 4 menunjukkan bahwa pengaruh konsentrasi dan frekuensi pemberian pestisida nabati dan kimia terhadap pertumbuhan dan hasil tanaman krisan tidak ada interaksi terhadap pengendalian Liriomyza sp. yang diamati 
pada variabel tinggi tanaman dan jumlah daun. Pertumbuhan tanaman krisan tidak terpengaruh adanya populasi Liriomyza sp. Hal ini disebabkan tingkat kerusakan akibat serangan Liriomyza sp. masih rendah, maka daya pertumbuhan tanaman krisan mampu mengkompensasi kerusakan tersebut (Suryaningsih, 2006). Selain itu, hal ini diduga juga oleh media tanahnya sudah cukup tersedia unsur haranya. Media tumbuh yang digunakan tanah dan pupuk kandang yang sudah terfermentasi perbandingan $1 \mathrm{~m}^{2} / 10 \mathrm{~kg}$, hal ini sudah cukup subur untuk mendukung tanaman sampai pertumbuhan generatif, apalagi pada media tersebut diberikan pupuk anorganik sampai umur tanaman 10 mst. Tanaman krisan yang diperlakukan dengan konsentrasi dan frekuensi pemberian pestisida nabati maupun kimia cukup subur dan memberikan pengaruh sama, terbukti bahwa hasil panen bunga potong krisan sama-sama masuk grade A.

Hal ini juga ditunjukkan dari panjang tangkai tanaman, jumlah daun $2 / 3$ bag tangkai bunga, diameter bunga (Tabel 5). Sedangkan untuk diameter tangkai bunga penerapan biopestisida dengan konsentrasi $10 \%$ dan pestisida kimia menunjukkan hasil yang lebih baik. Keadaan tangkai paling baik justru dengan aplikasi biopestisida $10 \%$ dengan frekuensi $2 \mathrm{x}$. Keberadaan benda asing (sisa hama / penyakit) semua aplikasi menunjukkan hasil yang berbeda dengan kontrol.

Kerusakan bunga dan daun (bekas serangan hama dan penyakit) atau dampak serangan hama ini terhadap hasil tergantung pada jenis tanaman, saat serangan terjadi, dan tingkat kerusakan. Secara umum kerusakan karena kerokan larva lebih merugikan daripada kerusakan karena tusukan ovipositor. Hal ini terjadi pada bunga potong krisan, bunga dan daun (bekas serangan hama dan penyakit) dapat menurunkan grade sekaligus harga jual. Syarat penjualan bunga potong krisan dengan menyertakan 2/3 bagian daun yang atas.

Tabel 3. Tinggi Tanaman Krisan Minggu 1 -13

\begin{tabular}{|c|c|c|c|c|c|c|c|c|c|c|c|c|c|}
\hline Kombinasi & N1 & $\mathrm{N} 2$ & N3 & $\mathrm{N} 4$ & N5 & N6 & N7 & N8 & N9 & N10 & N11 & N12 & N13 \\
\hline $\begin{array}{l}\text { Tanpa } \\
\text { perlakuan }\end{array}$ & $10,45^{\mathrm{a}}$ & $14,20^{\mathrm{a}}$ & $19,60^{a}$ & $25,90^{\mathrm{a}}$ & $35,10^{\mathrm{a}}$ & $45,90^{a}$ & $54,10^{a}$ & $63,25^{a}$ & $67,60^{a}$ & $74,40^{a}$ & $76,80^{a}$ & $80,30^{a}$ & $83,85^{a}$ \\
\hline $\begin{array}{l}\text { Biopestisida } \\
5 \% 1 \mathrm{kali}\end{array}$ & $10,88^{\mathrm{a}}$ & $15,93^{\mathrm{a}}$ & $22,02^{\mathrm{a}}$ & $28,85^{\mathrm{a}}$ & $38,65^{\mathrm{a}}$ & $48,33^{\mathrm{a}}$ & $57,77^{\mathrm{a}}$ & $68,60^{\mathrm{a}}$ & $75,40^{\mathrm{a}}$ & $80,48^{a}$ & $82,98^{\mathrm{a}}$ & $87,10^{\mathrm{a}}$ & $89,77^{\mathrm{a}}$ \\
\hline $\begin{array}{l}\text { Biopestisida } \\
10 \% 1 \mathrm{kali}\end{array}$ & $10,50^{\mathrm{a}}$ & $14,82^{\mathrm{a}}$ & $20,22^{\mathrm{a}}$ & $27,72^{\mathrm{a}}$ & $37,50^{\mathrm{a}}$ & $46,87^{\mathrm{a}}$ & $55,02^{\mathrm{a}}$ & $64,97^{\mathrm{a}}$ & $70,47^{\mathrm{a}}$ & $74,55^{\mathrm{a}}$ & $77,97^{\mathrm{a}}$ & $81,47^{\mathrm{a}}$ & $84,53^{a}$ \\
\hline Kimia 1 kali & $10,53^{\mathrm{a}}$ & $14,87^{\mathrm{a}}$ & $20,50^{\text {a }}$ & $27,48^{\mathrm{a}}$ & $38,12^{\mathrm{a}}$ & $49,46^{a}$ & $59,05^{\text {a }}$ & $70,89^{\mathrm{a}}$ & $76,60^{\text {a }}$ & $83,05^{\text {a }}$ & $86,57^{\mathrm{a}}$ & $90,66^{\mathrm{a}}$ & $93,43^{\mathrm{a}}$ \\
\hline $\begin{array}{l}\text { Biopestisida } \\
5 \% 2 \text { kali }\end{array}$ & $10,92^{\mathrm{a}}$ & $15,63^{\mathrm{a}}$ & $21,36^{\mathrm{a}}$ & $28,32^{\mathrm{a}}$ & $38,48^{\mathrm{a}}$ & $47,55^{\mathrm{a}}$ & $57,40^{\mathrm{a}}$ & $66,75^{\mathrm{a}}$ & $73,37^{\mathrm{a}}$ & $77,17^{\mathrm{a}}$ & $81,88^{\mathrm{a}}$ & $85,43^{\mathrm{a}}$ & $88,07^{\mathrm{a}}$ \\
\hline $\begin{array}{l}\text { Biopestisida } \\
10 \% 2 \text { kali }\end{array}$ & $10,13^{\mathrm{a}}$ & $14,67^{\mathrm{a}}$ & $20,02^{\mathrm{a}}$ & $26,83^{\mathrm{a}}$ & $36,33^{a}$ & $47,20^{\mathrm{a}}$ & $56,57^{\mathrm{a}}$ & $67,94^{\mathrm{a}}$ & $74,89^{a}$ & $79,51^{\mathrm{a}}$ & $84,30^{a}$ & $89,41^{\mathrm{a}}$ & $92,50^{\mathrm{a}}$ \\
\hline Kimia 2 kali & $10,62^{a}$ & $15,73^{\text {a }}$ & $21,67^{\mathrm{a}}$ & $28,53^{\text {a }}$ & $37,90^{\mathrm{a}}$ & $48,22^{\mathrm{a}}$ & $58,02^{\mathrm{a}}$ & $69,17^{\mathrm{a}}$ & $75,34^{\mathrm{a}}$ & $81,20^{\mathrm{a}}$ & $84,58^{\mathrm{a}}$ & $88,72^{\text {a }}$ & $92,17^{\mathrm{a}}$ \\
\hline
\end{tabular}

Keterangan : $\mathrm{N}$ adalah tinggi tanaman $(\mathrm{cm})$

Tabel 4. Jumlah Daun Tanaman Krisan minggu $1-13$

\begin{tabular}{|c|c|c|c|c|c|c|c|c|c|c|c|c|c|}
\hline Kombinasi & JD1 & JD 2 & JD 3 & JD 4 & JD 5 & JD 6 & JD 7 & JD 8 & JD 9 & JD 10 & JD 11 & JD 12 & JD 13 \\
\hline $\begin{array}{l}\text { Tanpa } \\
\text { perlakuan }\end{array}$ & $6,10^{\mathrm{a}}$ & $10,20^{\mathrm{a}}$ & $10,80^{\mathrm{a}}$ & $11,40^{\mathrm{a}}$ & $16,10^{\mathrm{a}}$ & $22,20^{\mathrm{a}}$ & $26,50^{\mathrm{a}}$ & $32,10^{\mathrm{a}}$ & $33,50^{\mathrm{a}}$ & $34,60^{\mathrm{a}}$ & $33,60^{\mathrm{a}}$ & $25,30^{\mathrm{a}}$ & $24,30^{\mathrm{a}}$ \\
\hline $\begin{array}{l}\text { Biopestisid } \\
\text { a } 5 \% 1 \mathrm{kali}\end{array}$ & $6,07^{\mathrm{a}}$ & $10,03^{\mathrm{a}}$ & $10,17^{\mathrm{a}}$ & $11,40^{\mathrm{a}}$ & $16,67^{\mathrm{a}}$ & $20,23^{\text {a }}$ & $25,27^{\mathrm{a}}$ & $28,27^{\mathrm{a}}$ & $31,23^{\mathrm{a}}$ & $31,43^{\mathrm{a}}$ & $31,37^{\mathrm{a}}$ & $26,40^{\mathrm{a}}$ & $26,40^{\mathrm{a}}$ \\
\hline $\begin{array}{l}\text { Biopestisid } \\
\text { a } 10 \% 1 \\
\text { kali }\end{array}$ & $5,83^{a}$ & $9,50^{\mathrm{a}}$ & $9,83^{\mathrm{a}}$ & $11,47^{\mathrm{a}}$ & $15,67^{\mathrm{a}}$ & $20,40^{\mathrm{a}}$ & $24,07^{\mathrm{a}}$ & $29,07^{\text {a }}$ & $30,37^{\mathrm{a}}$ & $30,37^{\mathrm{a}}$ & $29,63^{\text {a }}$ & $23,83^{\mathrm{a}}$ & $23,83^{a}$ \\
\hline $\begin{array}{l}\text { Kimia } 1 \\
\text { kali }\end{array}$ & $5,53^{a}$ & $9,50^{\mathrm{a}}$ & $9,67^{\mathrm{a}}$ & $11,21^{\mathrm{a}}$ & $15,41^{\mathrm{a}}$ & $20,32^{\mathrm{a}}$ & $24,12^{\mathrm{a}}$ & $28,61^{\mathrm{a}}$ & $29,96^{\mathrm{a}}$ & $30,04^{\mathrm{a}}$ & $30,04^{\mathrm{a}}$ & $24,86^{\mathrm{a}}$ & $24,86^{\mathrm{a}}$ \\
\hline $\begin{array}{l}\text { Biopestisid } \\
\text { a } 5 \% 2 \\
\text { kali }\end{array}$ & $6,10^{a}$ & $10,10^{\mathrm{a}}$ & $10,20^{\mathrm{a}}$ & $10,67^{\mathrm{a}}$ & $14,80^{\mathrm{a}}$ & $19,80^{\text {a }}$ & $24,27^{\mathrm{a}}$ & $28,80^{\mathrm{a}}$ & $31,43^{\mathrm{a}}$ & $31,40^{\mathrm{a}}$ & $31,40^{\mathrm{a}}$ & $25,63^{a}$ & $25,63^{a}$ \\
\hline $\begin{array}{l}\text { Biopestisid } \\
\text { a } 10 \% 2\end{array}$ & $5,53^{\mathrm{a}}$ & $9,50^{\mathrm{a}}$ & $9,87^{\mathrm{a}}$ & $10,33^{a}$ & $14,68^{\mathrm{a}}$ & $19,75^{\mathrm{a}}$ & $23,68^{\mathrm{a}}$ & $28,14^{\mathrm{a}}$ & $31,28^{\mathrm{a}}$ & $31,28^{\mathrm{a}}$ & $31,28^{\mathrm{a}}$ & $25,07^{\mathrm{a}}$ & $25,07^{\mathrm{a}}$ \\
\hline
\end{tabular}




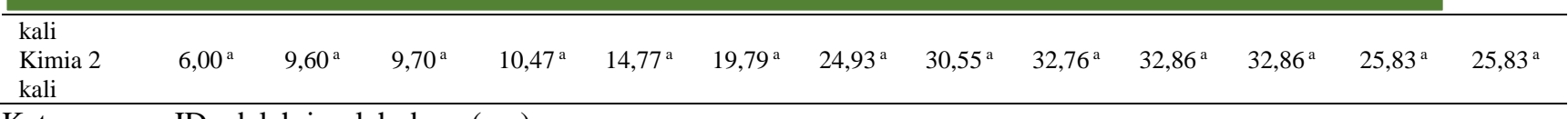

Keterangan : JD adalah jumlah daun (cm)

Tabel 5. Panjang Tangkai Tanaman (cm), Jumlah Daun 2/3 Bag Tangkai Bunga, Diameter Bunga (mm), Diameter Tangkai Bunga (mm), Benda Asing (Sisa hama / penyakit) (\%) dan Keadaan Tangkai

\begin{tabular}{lcccccc}
\hline Kombinasi & $\begin{array}{c}\text { Panjang tangkai } \\
\text { tanaman }(\mathrm{cm})\end{array}$ & $\begin{array}{c}\text { Jumlah daun 2/3 } \\
\text { bag tangkai bunga }\end{array}$ & $\begin{array}{c}\text { Diameter bunga } \\
(\mathrm{mm})\end{array}$ & $\begin{array}{c}\text { Diameter tangkai } \\
\text { bunga }(\mathrm{mm})\end{array}$ & $\begin{array}{c}\text { Benda asing (sisa } \\
\text { hama / penyakit) } \\
(\%)\end{array}$ & $\begin{array}{c}\text { Keadaan } \\
\text { tangkai }\end{array}$ \\
\hline $\begin{array}{l}\text { Tanpa } \\
\text { perlakuan }\end{array}$ & $76,00^{\mathrm{a}}$ & $2,00^{\mathrm{a}}$ & $77,50^{\mathrm{a}}$ & $4,80^{\mathrm{a}}$ & $5,80^{\mathrm{a}}$ & $2,70^{\mathrm{a}}$ \\
$\begin{array}{l}\text { Biopestisida } \\
5 \% \text { 1 kali }\end{array}$ & $73,96^{\mathrm{a}}$ & $1,96^{\mathrm{a}}$ & $75,51^{\mathrm{a}}$ & $5,14^{\mathrm{abc}}$ & $3,41^{\mathrm{b}}$ & $2,76^{\mathrm{ab}}$ \\
$\begin{array}{l}\text { Biopestisida } \\
\begin{array}{l}10 \% \text { k kali } \\
\text { Kimia 1 }\end{array}\end{array}$ & $74,11^{\mathrm{a}}$ & $1,96^{\mathrm{a}}$ & $76,96^{\mathrm{a}}$ & $5,25^{\mathrm{bc}}$ & $3,50^{\mathrm{b}}$ & $2,93^{\mathrm{ab}}$ \\
kali \\
$\begin{array}{l}\text { Biopestisida } \\
5 \% \text { 2 kali }\end{array}$ & $73,86^{\mathrm{a}}$ & $2,00^{\mathrm{a}}$ & $76,64^{\mathrm{a}}$ & $5,24^{\mathrm{bc}}$ & $3,43^{\mathrm{b}}$ & $2,93^{\mathrm{ab}}$ \\
$\begin{array}{l}\text { Biopestisida } \\
10 \% \text { kali }\end{array}$ & $73,07^{\mathrm{a}}$ & $2,00^{\mathrm{a}}$ & $75,43^{\mathrm{a}}$ & $5,10^{\mathrm{abc}}$ & $3,87^{\mathrm{b}}$ & $2,77^{\mathrm{ab}}$ \\
$\begin{array}{l}\text { Kimia 2 } \\
\text { kali }\end{array}$ & $76,00^{\mathrm{a}}$ & $2,00^{\mathrm{a}}$ & $77,89^{\mathrm{a}}$ & $5,47^{\mathrm{c}}$ & $3,21^{\mathrm{b}}$ & $3,00^{\mathrm{b}}$ \\
\hline
\end{tabular}

Populasi Liriomyza sp. dapat teramati sejak satu minggu setelah tanam (mst) yaitu 5,87 ekor/perangkap. Populasi imago tersebut dapat ditemukan lebih awal apabila perangkap kuning dipasang lebih awal. Hal ini sesuai hasil pengamatan Martini et al. (2005) menunjukkan imago Liriomyza sp. mulai ditemukan pada tanaman krisan yang berumur 2 mst, larva Liriomyza sp. mulai menyerang sejak kotiledon terbentuk, artinya imago sudah ada di lapangan di awal penanaman. Liriomyza sp. telah berada di pertanaman sebelum tanaman krisan ditanam karena sumber koloni hama ini adalah tanaman inang di sekitarnya, seperti kentang dan terong.

Gejala awal serangan Liriomyza sp. ditunjukkan oleh adanya bintik-bintik putih dan korokan berupa terowongan kecil yang berliku pada permukaan bagian atas daun. Bintik putih dan korokan tersebut hanya terdapat pada permukaan bagian atas daun, sedangkan permukaan daun bagian bawah tidak terdapat bintik putih ataupun korokan. Serangan berat mengakibatkan korokan tersebut mengering dan berwarna coklat seperti daun terbakar (Martini et al., 2005).

Aplikasi biopestisida dan kimia menurunkan serangan intensitas serangan pada krisan (Tabel 6 dan Gambar 1).
Serangan imago Liriomyza sp. mengalami penurunan setelah tanaman berumur 4 hingga $13 \mathrm{mst}$ (memasuki fase generatif tanaman). Selain itu pemasangan perangkap kuning juga menjadi salah satu teknik pengendalian yang cukup efektif untuk menekan populasi imago Liriomyza sp. Menurut Martini et al. (2005), perangkap berupa helaian kain berwarna kuning dan berperekat pada pertanaman kentang efektif menekan populasi lalat Liriomyza sp. Penurunan intensitas serangan pada pertanaman yang memasuki fase generatif juga disebabkan oleh karena pada awal fase generatif kandungan nutrisi pada daun masih tinggi, namun setelah itu akan mengalami penurunan. Apabila tanaman telah memasuki fase generatif, maka kandungan protein daun berkurang karena telah disalurkan ke bunga sehingga kurang sesuai untuk pertumbuhan dan perkembangan larva.

Perlakuan konsentrasi dan frekuensi pemberian pestisida nabati maupun kimia tidak beda nyata terhadap Keefektifan Relatif Pengendalian (KRP) lalat Liriomyza sp. pada tanaman krisan (Tabel 7 dan Gambar 2). Efektivitas perlakuan pestisida nabati dan kimia bahan aktif Abamektin dalam mengendalikan lalat Liriomyza sp. 
pada tanaman krisan adalah sama. Hal ini terbukti bahwa perlakuan penggunaan pestisida nabati dan pestisida kimia berbahan aktif Abamektin sangat efektif mengendalikan serangan Liriomyza sp. pada pertanaman krisan. Penelitian pendahulu sudah membuktikan bahwa hasil perhitungan KRP sebesar 68,36 \% dengan perilaku penggunaan insektisida berbahan aktif Abamektin efektif mengendalikan serangan Liriomyza sp. pada pertanaman krisan (Martini et al., 2005).

Intensitas serangan Liriomyza sp. dari semua perlakukan pestisida nabati maupun kimia menunjukkan perbedaan keefektifan setiap minggunya (Tabel 6 dan 7). Hal ini dapat dilihat dari intensitas serangan dari semua perlakuan yang menunjukkan paling rendah setiap pengamatan mingguan. Hal ini berarti aplikasi pestisida nabati dapat sebagai alternatif menggantikan penggunaan pestisida kimia dalam menekan kerusakan tanaman yang diakibatkan serangan Liriomyza sp. Penelitian pendahuluan mencatat bahwa Phrogonal (866) yaitu pestisida biorasional yang terbuat dari campuran ekstrak kasar 8 kg kacang babi (Tephrosia candida) $+6 \mathrm{~kg}$ umbi tanaman lengkuas (Alpinia galanga) + $6 \mathrm{~kg}$ umbi tanaman sereh wangi (Andropogon Nardus) sangat efektif mengendalikan OPT utama pada kentang, cabai, dan bawang merah (Suryaningsih,
2006).

Sereh wangi (Andropogon Nardus) mengandung molekul bioaktif senyawa sitral, sitronela, geraniol, mirsene, nerol, farnesol, metil heptenon, dan dipentena. Gugus seskuiterpen seperti farnesol adalah hasil metabolisme sekunder, memiliki aktivitas fisiologi biotoksin (racun) dan allergen. Senyawa lainnya banyak bersifat penghambat makan dan penolak karena berbentuk minyak atsiri yang mudah menguap. Lengkuas (Alpinia galanga) mengandung minyak atsiri komponen asetil sianat, sienol kamper, dan galangin, cara kerjanya sebagai biotoksin dan penolak (Suryaningsih, 2006).

Kandungan senyawa yang sudah ditemukan pada bawang putih diantaranya "Allicin" dan "sulfur ammonia acid allin". Sulfur ammonia acid allin ini oleh enzim Allicin lyase diubah menjadi piruvat acid, ammonia dan allicin anti mikroba, Tabel 6. Intensitas Serangan Liriomyza Sp. pada Tanaman Krisan minggu 1-13.

Selanjutnya allicin mengalami perubahan menjadi "diallyl sulphide". Ekstrak bawang putih dapat berfungsi sebagai penolak kehadiran serangga (Novizan, 2002). Senyawa allicin dan diallyl sulphide inilah yang memiliki banyak kegunaan dan berkhasiat untuk obat (Hasnah dan Hanif, 2010).

Tabel 6. Intensitas Serangan Liriomyza Sp. pada Tanaman Krisan minggu 1 -13

\begin{tabular}{|c|c|c|c|c|c|c|c|c|c|c|c|c|c|}
\hline Kombinasi & I1 & I2 & I3 & I4 & I5 & I6 & I7 & I8 & I9 & I10 & I11 & I12 & I13 \\
\hline $\begin{array}{l}\text { Tanpa } \\
\text { perlakuan }\end{array}$ & $0,00^{\mathrm{a}}$ & $0,00^{\mathrm{a}}$ & $3,04^{\mathrm{a}}$ & $5,28^{a}$ & $6,32^{\mathrm{a}}$ & $0,69^{a}$ & $6,23^{a}$ & $7,21^{\mathrm{a}}$ & $7,82^{\mathrm{a}}$ & $10,62^{a}$ & $12,53^{\mathrm{a}}$ & $18,94^{\mathrm{a}}$ & $22,69^{a}$ \\
\hline $\begin{array}{l}\text { Biopestisida } \\
5 \% 1 \mathrm{kali}\end{array}$ & $0,00^{\mathrm{a}}$ & $0,00^{\mathrm{a}}$ & $1,35^{\mathrm{b}}$ & $0,62^{\mathrm{b}}$ & $0,48^{\mathrm{b}}$ & $0,06^{\mathrm{b}}$ & $0,05^{b}$ & $0,13^{\mathrm{b}}$ & $0,21^{\mathrm{b}}$ & $0,19^{b}$ & $0,34^{\mathrm{b}}$ & $0,42^{\mathrm{b}}$ & $0,10^{\mathrm{b}}$ \\
\hline $\begin{array}{l}\text { Biopestisida } \\
10 \% 1 \text { kali }\end{array}$ & $0,00^{\mathrm{a}}$ & $0,00^{\mathrm{a}}$ & $1,09^{\mathrm{b}}$ & $0,94^{\mathrm{b}}$ & $0,69^{\mathrm{b}}$ & $0,00^{\mathrm{b}}$ & $0,00^{\mathrm{b}}$ & $0,17^{\mathrm{b}}$ & $0,19^{\mathrm{b}}$ & $0,18^{\mathrm{b}}$ & $0,27^{\mathrm{b}}$ & $0,36^{\mathrm{b}}$ & $0,42^{\mathrm{b}}$ \\
\hline Kimia 1 kali & $0,00^{\mathrm{a}}$ & $0,00^{\mathrm{a}}$ & $0,79^{\mathrm{b}}$ & $0,55^{\mathrm{b}}$ & $0,40^{\mathrm{b}}$ & $0,13^{\mathrm{b}}$ & $0,11^{\mathrm{b}}$ & $0,17^{\mathrm{b}}$ & $0,24^{\mathrm{b}}$ & $0,24^{\mathrm{b}}$ & $0,15^{\mathrm{b}}$ & $0,17^{\mathrm{b}}$ & $0,21^{\mathrm{b}}$ \\
\hline $\begin{array}{l}\text { Biopestisida } \\
5 \% 2 \mathrm{kali}\end{array}$ & $0,00^{\mathrm{a}}$ & $0,00^{\mathrm{a}}$ & $1,01^{\mathrm{b}}$ & $0,51^{\mathrm{b}}$ & $0,38^{\mathrm{b}}$ & $0,18^{\mathrm{b}}$ & $0,19^{\mathrm{b}}$ & $0,29^{\mathrm{b}}$ & $0,49^{\mathrm{b}}$ & $0,49^{\mathrm{b}}$ & $0,52^{b}$ & $0,74^{\mathrm{b}}$ & $0,70^{\mathrm{b}}$ \\
\hline $\begin{array}{l}\text { Biopestisida } \\
10 \% 2 \text { kali }\end{array}$ & $0,00^{\mathrm{a}}$ & $0,00^{\mathrm{a}}$ & $0,98^{\mathrm{b}}$ & $0,82^{\mathrm{b}}$ & $0,56^{\mathrm{b}}$ & $0,08^{\mathrm{b}}$ & $0,06^{\mathrm{b}}$ & $0,05^{\mathrm{b}}$ & $0,12^{\mathrm{b}}$ & $0,07^{\mathrm{b}}$ & $0,07^{\mathrm{b}}$ & $0,10^{\mathrm{b}}$ & $0,00^{\mathrm{b}}$ \\
\hline Kimia 2 kali & $0,00^{\mathrm{a}}$ & $0,00^{\mathrm{a}}$ & $1,13^{\mathrm{b}}$ & $1,02^{\mathrm{b}}$ & $0,75^{\mathrm{b}}$ & $0,00^{\mathrm{b}}$ & $0,05^{\mathrm{b}}$ & $0,04^{\mathrm{b}}$ & $0,10^{\mathrm{b}}$ & $0,10^{\mathrm{b}}$ & $0,26^{\mathrm{b}}$ & $0,35^{\mathrm{b}}$ & $0,10^{\mathrm{b}}$ \\
\hline
\end{tabular}

Keterangan : I adalah intensitas $\left(\times 10^{-2}\right)$ 
P-ISSN: 1858-1226; E-ISSN: 2723-4010

Desember 2020, Vol. 27 No. 2

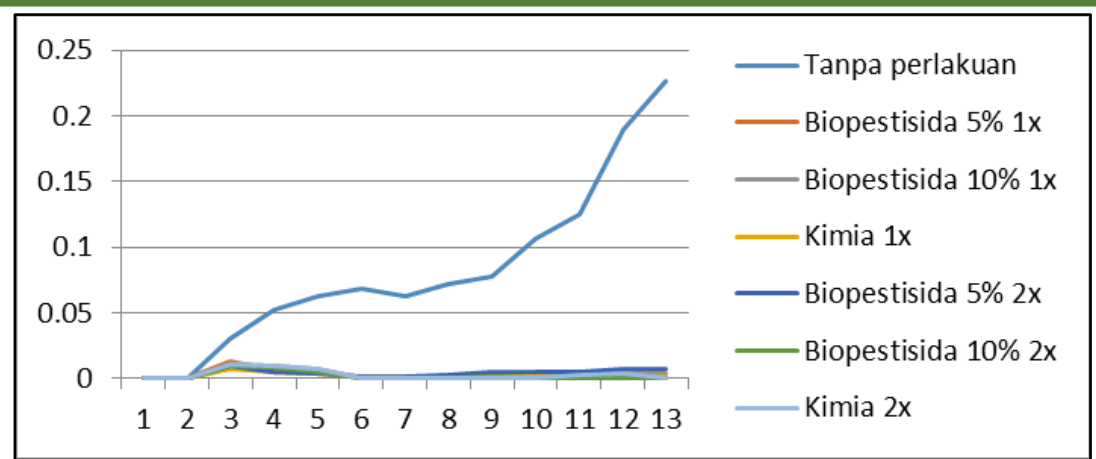

Gambar 1. Intensitas Serangan Liriomyza Sp. pada Tanaman Krisan

Tabel 7. Keefektifan Relatif Pengendalian Liriomyza Sp. Pada Tanaman Krisan (\%) Umur 3 Sampai 13

\begin{tabular}{lccccccccccc}
\hline Kombinasi & KRP3 & KRP4 & KRP5 & KRP6 & KRP7 & KRP8 & KRP9 & KRP10 & KRP 11 & KRP12 & KRP 13 \\
\hline $\begin{array}{l}\text { Biopestisida } \\
\text { 5\% 1x }\end{array}$ & $0,56^{\mathrm{a}}$ & $0,88^{\mathrm{a}}$ & $0,92^{\mathrm{a}}$ & $0,99^{\mathrm{a}}$ & $0,99^{\mathrm{a}}$ & $0,98^{\mathrm{a}}$ & $0,97^{\mathrm{a}}$ & $0,95^{\mathrm{a}}$ & $0,94^{\mathrm{a}}$ & $0,94^{\mathrm{a}}$ & $0,96^{\mathrm{a}}$ \\
$\begin{array}{l}\text { Biopestisida } \\
10 \% \text { 1x }\end{array}$ & $0,64^{\mathrm{a}}$ & $0,82^{\mathrm{a}}$ & $0,89^{\mathrm{a}}$ & $1,00^{\mathrm{a}}$ & $0,97^{\mathrm{a}}$ & $0,94^{\mathrm{a}}$ & $0,94^{\mathrm{a}}$ & $0,95^{\mathrm{a}}$ & $0,91^{\mathrm{a}}$ & $0,91^{\mathrm{a}}$ & $0,91^{\mathrm{a}}$ \\
Kimia 1x & $0,74^{\mathrm{a}}$ & $0,86^{\mathrm{a}}$ & $0,90^{\mathrm{a}}$ & $0,95^{\mathrm{a}}$ & $0,95^{\mathrm{a}}$ & $0,94^{\mathrm{a}}$ & $0,93^{\mathrm{a}}$ & $0,91^{\mathrm{a}}$ & $0,92^{\mathrm{a}}$ & $0,92^{\mathrm{a}}$ & $0,92^{\mathrm{a}}$ \\
$\begin{array}{l}\text { Biopestisida } \\
5 \% \text { 2x }\end{array}$ & $0,67^{\mathrm{a}}$ & $0,90^{\mathrm{a}}$ & $0,94^{\mathrm{a}}$ & $0,97^{\mathrm{a}}$ & $0,97^{\mathrm{a}}$ & $0,96^{\mathrm{a}}$ & $0,94^{\mathrm{a}}$ & $0,95^{\mathrm{a}}$ & $0,96^{\mathrm{a}}$ & $0,96^{\mathrm{a}}$ & $0,97^{\mathrm{a}}$ \\
Biopestisida & $0,68^{\mathrm{a}}$ & $0,84^{\mathrm{a}}$ & $0,91^{\mathrm{a}}$ & $0,99^{\mathrm{a}}$ & $0,99^{\mathrm{a}}$ & $0,99^{\mathrm{a}}$ & $0,98^{\mathrm{a}}$ & $0,93^{\mathrm{a}}$ & $0,93^{\mathrm{a}}$ & $0,93^{\mathrm{a}}$ & $0,93^{\mathrm{a}}$ \\
$\begin{array}{l}10 \% \text { 2x } \\
\text { Kimia 2x }\end{array}$ & $0,63^{\mathrm{a}}$ & $0,81^{\mathrm{a}}$ & $0,88^{\mathrm{a}}$ & $1,00^{\mathrm{a}}$ & $0,99^{\mathrm{a}}$ & $0,99^{\mathrm{a}}$ & $0,99^{\mathrm{a}}$ & $0,96^{\mathrm{a}}$ & $0,95^{\mathrm{a}}$ & $0,95^{\mathrm{a}}$ & $0,96^{\mathrm{a}}$ \\
\hline
\end{tabular}

Keterangan : KRP adalah keefektifan relatif pengendalian

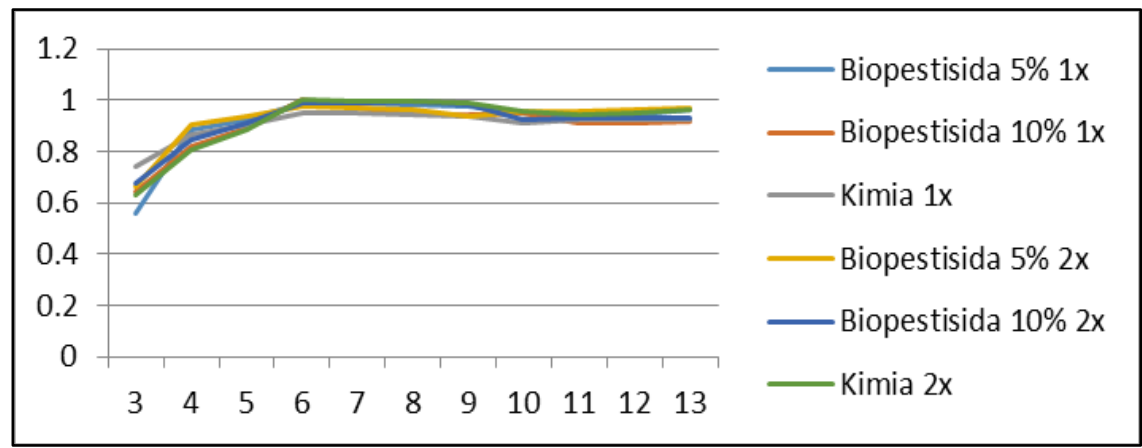

Gambar 2. Keefektifan Relatif Pengendalian Liriomyza Sp. pada Tanaman Krisan

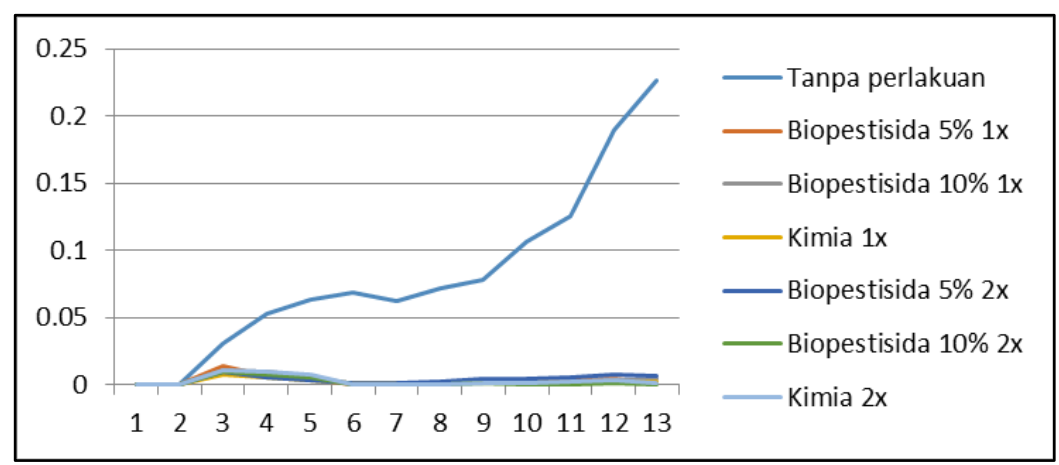

Gambar 3. Intensitas Serangan Liriomyza Sp. pada Tanaman Krisan 


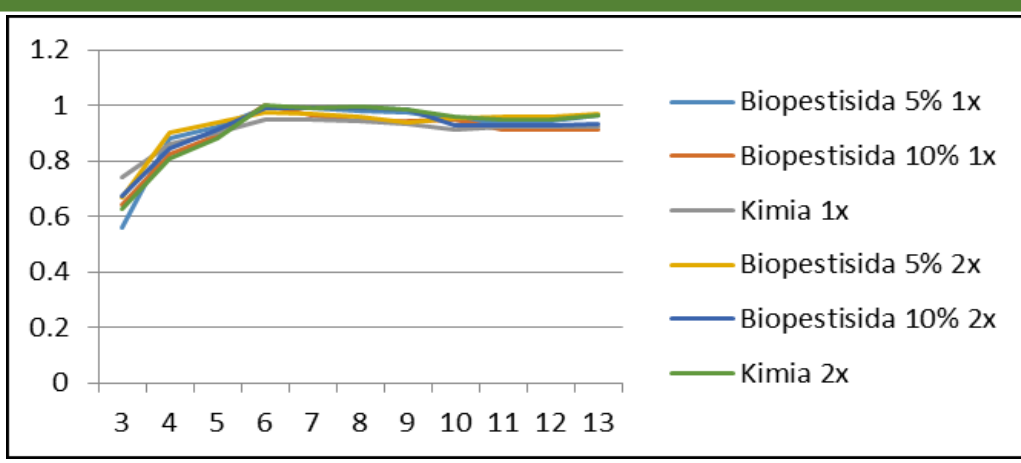

Gambar 4. Keefektifan Relatif Pengendalian Liriomyza Sp. pada Tanaman Krisan

Tanaman gadung mempunyai kelebihan mengandung senyawa antimakan, senyawa ini tidak membunuh, mengusir atau menjerat serangga hama, bersifat spesifik terhadap serangga sasaran, tidak mengganggu serangga lain, tetapi hanya menghambat selera makan serangga sehingga tumbuhan dan kelangsungan hidup organisme lainnya terlindungi (Faqih, 2002).

Menurut Butarbutar et al. (2013) bahwa umbi gadung mengandung suatu jenis racun yaitu dioscorin, diosgenin dan dioscin yang dapat menyebabkan gangguan saraf yang mengakibatkan pusing dan muntah-muntah pada larva sehingga larva lebih cepat mati. Umbi gadung juga memiliki kandungan beracun yang berupa senyawa glikosida sianogenik, alkaloid dioscorin dan dehydro dioscorin dan senyawa pahit yang terdiri dari saponin dan sapogenin yang tidak disukai larva Spodoptera litura dan juga mengandung senyawa dioscorin dan tanin yang bersifat toksik sehingga dapat digunakan sebagai insektisida. Selain itu umbi gadung mengandung steroid saponin, alkohol dan fenol yang efektif untuk mengendalikan hama ulat dan hama penghisap.

\section{SIMPULAN}

Penggunaan pestisida nabati dan kimia akan menurunkan intensitas serangan Liriomyza sp. pada tanaman krisan. Hasil ini menunjukkan bahwa penggunaan pestisida nabati tidak menghambat pertumbuhan serta mampu menurunkan intensitas serangan Liriomyza sp. pada tanaman krisan sama dengan pestisida kimia. Hal ini ditunjukkan dari nilai Keefektivitas Relatif Pengendalian (KRP) pestisida nabati $(90,47 \%)$ dengan pestisida kimia $(85 \%)$ berpengaruh sama dalam mengendalikan serangan Liriomyza sp. pada pertumbuhan tanaman krisan.

\section{PUSTAKA ACUAN}

Baliadi, Y. dan Tengkano, W. (2009). Lalat Pengorok Daun, Liriomyza sp. (Diptera: Agromyzidae), Hama Baru pada Tanaman Kedelai di Indonesia. diakses dari www. pustaka.litbang. deptan.go.id/publikasi

Butarbutar, R., Tobing, M. C., dan Tarigan, M. U. (2013). Pengaruh Beberapa Jenis Pestisida Nabati Untuk Mengendalikan Ulat Grayak Spodoptera litura F. (Lepidoptera: Noctuidae) pada Tanaman Tembakau Deli di Lapangan. diakses dari www. jurnal.USU.ac.id

Faqih, M. (2002). Pengaruh Berbagai Konsentrasi Ekstrak Umbi Gadung (Dioscorea hispida Dennts) Terhadap Kematian Larva Nyamuk Aedes aegypti (Studi Eksperimen Laboratorium). diakses dari www.UNIMUS.ac.id

Handajaningsih, M. dan Wibisono, T. (2009). Pertumbuhan dan Pembungaan Krisan dengan Pemberian Abu Janjang Kelapa Sawit Sebagai Sumber Kalium. diakses dari www.UNIB.ac.id

Hasnah dan Hanif, U. 2010. Efektivitas Ekstrak Bawang Putih terhadap 
Mortalitas Sitophilus zeamais M pada Jagung di Penyimpanan. Jurusan Hama dan Penyakit Tumbuhan Jurusan Pertanian UNSYIAH, Banda Aceh Darusalam. J. Floratek 5:1-10

Herlinda, S. (2003). Jenis Tumbuhan Inang Liriomyza sativae Blanchard dan Kerusakan yang diakibatkannya pada tanaman tomat di daerah dataran rendah Sumatera Selatan. Prosiding Seminar Lokakarya Nasional 65 "Pembangunan Pertanian Berkelanjutan dalam Era Otonomi Daerah dan Globalisasi, Palembang 23 Mei 2003". Jurusan Hama dan Penyakit Tumbuhan, Fakultas Pertanian, UNSRI Jl. Raya PalembangPrabumulih, Km 32, Inderalaya, Ogan Komering Ilir.

Martini T., Hendrata, R., dan Masyhudi, MF. (2005). Populasi dan Serangan Pengorok Daun Liriomyza sp. serta Peran Abamektin Dalam Pengendaliannya Pada Adaptasi Krisan di D.I.Yogyakarta. diakses dari www . yogya.litbang.deptan.go.id.

Novizan, (2002) Membuat dan Memanfaatkan Pestisida Ramah Lingkungan. Jakarta PT Agromedia

\section{Pustaka.}

Nugraheni, E. D. dan Paiman. (2010). Pengaruh Konsentrasi dan Frekuensi Pemberian Pupuk Urin Kelinci terhadap Pertumbuhan dan Hasil Tomat (Lycopersicum esculentum Mill). diakses dari www.UPY.ac.id

Pedoman Pengenalan dan Pengendalian OPT Benih Tanaman Anggrek dan Krisan (2011). Jakarta. Direktorat Perlindungan Hortikultura. Ditjen Hortikultura. Kementerian Pertanian.

Suryaningsih, E. (2006). Pengendalian Lalat Pengorok Daun pada Tanaman Kentang Menggunakan Pestisida Biorasional Dirotasi Dengan Pestisida Sintetik Secara Bergiliran. diakses dari www.hortikultura.litbang.deptan.go.id

Taman Budidaya Krisan di Yogyakarta., (2008). Dalam Direktorat Perbenihan dan Sarana Produksi. Produksi Benih Krisan. Direktorat Jendral Hortikultura. diakses dari www. pustaka.litbang. deptan.go.id/publikasi

Winarno, V. C. (2013). Efektivitas Pestisida Nabati (Mimba, Gadung, Laos dan Serai) Terhadap Hama Pada Tanaman Kubis (Brassica oleracea L.). diakses dari www.UPNjatim.ac.id

DOI : 